\title{
Kawashima and the changing focus on Japanese legal consciousness: a selective history of the sociology of law in Japan
}

\author{
Masayuki Murayama* \\ School of Law, Meiji University
}

\begin{abstract}
Kawashima's well-known arguments on Japanese legal consciousness represent characteristic concerns of Japanese socio-legal scholarship: comparison between Japan and the West on the one hand, and law and practice on the other. Such concerns originated much earlier, before World War II. Suehiro, the early founder, relied on Ehrlich's idea of living law to make law fit social reality. In contrast, Kawashima urged Japanese people to make modern law 'our living law'. He also argued that Japanese consciousness was the main cause of the small volume of litigation. This thesis became a focus of empirical research by Japanese and foreign scholars. Kawashima played a significant role in establishing the sociology of law as a subject in law. In subsequent empirical studies, Kawashima's thesis has been critically assessed. Yet the sociology of law as an empirical science and the characteristic concerns his work represents are distinctive features of the sociology of law in Japan.
\end{abstract}

\section{Introduction}

The Japanese Association of Sociology of Law (JASL) was established in I947, only two years after the end of World War II. This indicates that there was widespread interest in the sociology of law even before and during World War II. In fact, JASL is the oldest national association in the field of law and social sciences among the existing national associations in the world.

Why was there so much interest in the sociology of law in Japan? The answer partly lay in the fact that Japanese laws, which had been imported from Europe at the end of the nineteenth century, were not consistent with social practice in pre-war Japanese society. The Meiji government tried to import Western laws as quickly as possible, although the government did not embrace the individualism and universalistic values inherent in Western laws. ${ }^{\mathrm{I}}$ The main reason for the speedy importation of Western laws was that the government was concerned with the preservation of national independence against Western colonisation and wanted to abolish as soon as possible the unequal treaties with Western countries, which included an extra-territoriality clause for foreign nationals.

* I thank David Nelken and the anonymous reviewer for their comments on drafts, which helped improve the paper. I am also grateful to Yukino Nakashima at Columbia University Law School Library for helping me work with Japanese materials.

I The Meiji government urged people to introduce Western technologies while keeping the Japanese 'soul'. Apparently Western laws were imported as Western technologies, but it was obvious that importing laws would be importing values inherent in them. As a result, how to circumscribe the significance of individualistic and universalistic values of Western laws and to preserve the traditional values against them became a significant political agenda of the government. 
Therefore, the government invited lawyers from Europe to legislate Western style codes and established the imperial constitutional system. ${ }^{2}$

This particular way of importing Western laws had significant and lasting impacts on Japanese legal scholarship, which developed characteristic concerns: first, an interest in comparing law and practice between Japan and the West, in which the West was often idealised; 3 second, a focus on comparing laws and social realities in Japan, as laws were mostly imported from the West and thus 'foreign' to people's lives. These concerns were also shared by Takeyoshi Kawashima, who presented influential and sometimes controversial hypotheses of Japanese legal behaviour.

This paper, while looking back at the development of the sociology of law in Japan from its emergence to the latest period, pays attention mainly to Kawashima's works, putting them in a larger historical context. Its purpose is to show how his works affected subsequent research and how they were also critically assessed by the studies of later generations. The paper divides the relevant history into three stages: (I) the emergence of the sociology of law up to the end of World War II, which will place Kawashima's arguments in a broader context; (2) the establishment of the sociology of law as social science from the post-war period to the I970s, when Kawashima made his well-known arguments about Japanese legal consciousness; and (3) the proliferation of empirical studies in the sociology of law since the I980s, the period when Kawashima's theoretical and empirical arguments were assessed more critically. In the first stage, the sociology of law was born as a close sibling of the free law theory ${ }^{4}$ and sociological jurisprudence, as law professors were concerned with gaps between statutes, on the one hand, and traditional practice and social changes triggered by industrialisation, on the other. ${ }^{5}$ However, in the process of its post-war development, the sociology of law was clearly differentiated from jurisprudence and legal theories, and sociological studies of law were increasingly conducted by empirical social scientists, rather than law professors, ${ }^{6}$ though most of the empirical scholars had legal backgrounds. Kawashima, while teaching the law of property, began to teach the sociology of law, and, as we will see later, played a central role in introducing social sciences to empirical research on law. Most empirical studies tried to find and explain actual practice, as distinguished from legal provisions. But, at the same time, they were explicitly or tacitly comparative. Kawashima's arguments about Japanese legal consciousness clearly show these characteristics, pointing out pre-modern social practice in contrast with Western modern legal consciousness. Throughout its long history, the sociology of law has been considered to be an empirical science designed to provide information about how the law and legal institutions actually function.

2 Imperial universities were established for professors to introduce the newest and the most advanced thinking from Western countries as quickly as possible.

3 Hideo Tanaka pointed out that foreign laws and their doctrines were often introduced uncritically without paying attention to how they functioned under different social conditions in foreign countries (Tanaka, I980). As Tanaka's criticism indicates, concern with practice emerged later.

4 The so-called free law theory had various versions (e.g. Mito, I9I2). In general it emphasised the creative nature of legal interpretation when a judge applied a statutory provision. When, how and to what extent a jurist could be free to be creative differed among proponents. But, for the early development of the sociology of law in Japan, Ehrlich's version, which is explained in the following text, was most significant.

5 This concern with 'gaps' did not lead to the same kind of studies in Japan as described for Dutch sociology of law by Hertogh (20I2). It was expected that legal provisions were often not effective. Finding out actual social practice was important, however, so as to interpret a legal provision to make it fit the social reality and to legislate new laws where there was no law regulating certain social activities, such as when introducing labour contracts for factory workers.

6 Until the early I970s, empirical work, typically fieldwork to find out living law, was conducted by civil law professors. From the I970s, legal sociologists began to have chairs of the sociology of law at universities and to teach the subject as a social science. 


\section{The birth of the sociology of law in Japan7}

The idea of the sociology of law was first introduced into Japan around I920. Already in the I9Ios it seemed that some legal scholars noticed the publication of Eugen Ehrlich's Grundlegung der Soziologie des Rechts, published in I9I3, and the high reputation of his work in the US. Kenzo Takayanagi, a scholar in Anglo-American law, visited Ehrlich in Switzerland in I9I9 and asked him to contribute to the law review issued by the Faculty of Law at the Imperial University of Tokyo. His article, 'Gesetz und lebendes Recht' and its Japanese translation were published in the law review Hogaku Kyokai Zassi in I920 (Ehrlich, I920). In this paper, Ehrlich contrasted statutory provisions and living law, saying that Japan could legislate the civil code most similar to the first draft of the German civil code in the I9IOs, as German provisions adopted from Roman laws were already general and abstract enough for another country to import them, while living law as rules of conduct differed from one country to another. Ehrlich argued that legal scholars had to find living law in a society, so that jurists could fill concrete meanings in abstract provisions. He emphasised that the knowledge of living law in a society was necessary to adjudicate, educate and legislate properly, and proposed setting up a research institute, just like a national census bureau, to collect data on the living law.

Another paper by Ehrlich, 'Die Soziologie des Rechts', appeared in Hogaku Kyokai Zasshi in I922, together with a Japanese translation and introduction in which Takayanagi explained the contemporary trends of legal thought in the German academic world (Ehrlich, I922a). ${ }^{8}$ In this paper, Ehrlich articulated the idea of living law as social order, and argued that social scientists of law should observe the totality of law in relation to a society, and integrate written laws into social relations.

The idea of sociological jurisprudence, advocated by Roscoe Pound, was also introduced during this period. Law professors specialised in civil law and in criminal law wrote articles on Pound's sociological jurisprudence (Ono, I924; Wagatsuma, I926a), ${ }^{9}$ which shows that academic interests in empirical studies were not confined within a small circle.

Ehrlich's idea of living law seemed to be accepted among civil law professors, partly because the free law movement had already been introduced by law professors by that time (Mito, I 9 I 2; Nakada, I9I3). I0 The strong interests in free law theories among Japanese legal scholars resulted from the fact that social practice among the Japanese people often differed from what the Civil Code provided. A typical example was marriage. Marriage in Japanese agrarian communities was social marriage, which did not require any legal or religious procedure, while the Civil Code required a marrying couple to submit a legal document (Nakagawa, I926). Many men and women failed to follow the procedure and women could not get legal protection when their de facto marriages failed. The court later developed a theory of illegal breach of marriage engagement to protect abandoned wives. ${ }^{\text {II }}$ In this way, lawyers were concerned with learning social practice and interpreting a written law to fit the reality.

At the same time, industrial urbanisation gradually began to occur around the turn of the century. As a result, the Factory Act was legislated to protect factory workers in I9I I and it came

7 The following description of the history is necessarily selective, as it focuses on what can be called the precursors to Kawashima's arguments about Japanese legal consciousness.

8 The English translation of the paper was published in the Harvard Law Review in the same year (Ehrlich, I922b).

9 Wagatsuma's paper was an introduction to Pound's sociological jurisprudence, based on Pound's paper in German, 'Soziologische Jurisprudenz in Amerika', in Jahrbuch fuer Soziologie: Eine international Sammlung, edited by G. Salomon. In this paper, Wagatsuma criticised German legal scholarship, saying that both Jehring and Ehrlich had not changed German conceptual jurisprudence, which kept its isolation from the real world intact.

Io There were opponents to the idea of free law among law professors. For instance, Uesugi, a constitutional law professor, emphasised that free law theories denied the existence of statutory law and eventually the sovereignty of a state (Uesugi, I9I3).

I I Daishin'in Minji Rengobu Hanketsu, 26 January I9I5. 
into effect in I9r6. As disputes between tenants and landlords increased in urban centres, new statutes were enacted to regulate rent contracts and conciliate rent disputes in early igros. Disputes between tenant farmers and landlords also increased during the same period. ${ }^{\mathrm{I2}}$ All these social upheavals indicated that the Civil Code could not regulate new social relationships properly. In other words, Japan began to experience social changes similar to those that prompted the birth of the free law movement in Germany and sociological jurisprudence in the US. ${ }^{13}$

Although the free law theory came to Japan from Germany and France, academic impetus for research on living law mainly came from the US, as well as from Ehrlich himself. Izutaro Suehiro, a civil law professor who later became the early founder of the sociology of law in Japan, wanted to study in Germany in I9I4, but could not go there, because World War I started that same year. Instead, Suehiro went to the US to study at the University of Chicago Law School, as his colleague, Kenzo Takayanagi, was there, having come from Harvard Law School, where he studied sociological jurisprudence (Takayanagi and Takahashi, I9I5).

At Chicago, Suehiro encountered the case method and realised that specific and concrete facts were crucial in legal interpretation, while developing deep doubt about the German way of legal interpretation. ${ }^{\text {I4 }}$ After coming back to Japan, he set up a study group of court judgments to develop legal interpretation focusing on facts. ${ }^{15}$ At the same time, he got involved in government research on the customary practices of tenant holdings, especially permanent tenants, among peasants. When a conciliation procedure was set up to cope with the increase of disputes between tenant farmers and landlords, he published a book in which he explained how the reorganisation of land use and ownership after the Meiji Restoration overlooked the customary practice of land use during the Tokugawa period, including the use of commons, and argued for the need to protect peasants in such a way as to motivate them to live from agriculture (Suehiro, I924). ${ }^{\text {I6 }}$

Suehiro also began to teach labour law around I92I, soon after coming back from his study abroad. ${ }^{17}$ He later published a book on labour law in 1926. In the introduction to a chapter on

I 2 For the causes of disputes between tenant farmers and their landlords, and the effects of the conciliation procedure, see Vanoverbeke (2004).

I3 Around the turn of the century, socialism began to have influence in Japan and, after World War II in particular, Marxism became more influential among legal scholars. Wagatsuma, a famous civil law professor, discussed Marx's historical materialism as a social scientific method (Wagatsuma, I926b, p. I232).

I4 At Chicago, he made up his mind to say ‘adieu' to the German way of legal interpretation (Suehiro et al., I 948 , p. 563).

I5 The introduction of the first volume of their studies on Daishin-in [Supreme Court] judgments was taken as Suehiro's declaration of his new method (Minpo Hanrei Kenkyukai, I923, pp. I-8). The published Daishinin decisions at that time did not include the facts of the cases. Suehiro criticised this and the Daishin-in began to include facts later (Minpo Hanrei Kenkyukai, I923, p. 8). This study group had a significant impact on the legal scholarship in the field of civil law. Kawashima later recalled his encounter with Suehiro when he made a presentation at a group meeting for the first time. According to the Civil Law, a tenant farmer could not maintain his tenant contract against a new landowner without his consent. The issue of the case was whether a tenant farmer could keep crops from the land when a creditor of the landowner tried to seize the crops for non-payment. The ownership of the land had been transferred from the landlord to the creditor as the guarantee of the credit. At Daishin-in, the creditor won the case and Kawashima supported the decision. According to Kawashima, Suehiro got angry with his opinion, saying to him: 'Your argument is based on conceptual jurisprudence. It is impossible that a person who actually raised rice cannot obtain the crops. You say that is the case in Germany. Such an argument cannot stand as a reason. Look at the substance of the problem.' Since then, Kawashima kept thinking about how to study court judgments (Kawashima, I978, pp. 63-72).

I6 Suehiro visited Ehrlich in Switzerland after he moved from the US to France. He later said that he felt ashamed when he could not answer a question from Ehrlich about the history of Japanese farming (Rokumoto and Yoshida, 2007, pp. 25-26).

I7 Suehiro et al. (I948, p. 58I). 
legislating a law of labour unions, he emphasised that the legislature had to have detailed knowledge of social relationships which the law would regulate, and also clear understandings of the effects of legal means, because legal means might not be able to achieve everything that the law would intend to achieve (Suehiro, I926, pp. Io-22). Here we can clearly see that Suehiro adopted sociological jurisprudence to discuss the proposed statute of labour unions.

It could be argued that these works of Suehiro can be considered to be in legal scholarship rather than the sociology of law, as his main concern was with how to use the law in a pragmatic way. However, he recognised the need for an empirical science of law independent of traditional legal scholarship (Suehiro, I95I). Based on his idea of scientific research of the law, Suehiro led a group of legal scholars to conduct field research on the living law in North China for four years from I940. According to his guidelines for the research, the purpose of the research was to describe the legal custom practised in Chinese society. But he emphasised that the research would look at effective norms, 'living law', and the dynamics in which new social forces clashed with the traditional social order. What Suehiro called 'living law' in the guidelines was not traditional customs as such, but effective social norms that people actually complied with as rules of conduct, social norms that were affected by formal legal provisions, traditional customs and all other social, political and economic forces. ${ }^{18} \mathrm{He}$ warned against imposing legal theories or categories upon facts, but urged researchers to observe and report facts as they existed (Suehiro, 1940). Although this research was criticised for its political implications, ${ }^{19}$ it provided valuable research experience to participating legal scholars.

As Suehiro taught the civil law, especially property law and labour law, academic interests in the sociology of law were particularly strong in these fields of law. Michitaka Kaino was one of the participants in the research in China and he published two books on land law and the right to commons. These books were widely read and they brought increasing interest in the sociology of law (Kaino, I943a, I943b). Takeyoshi Kawashima also carried out research in rural villages, ${ }^{20}$ concerning tenant farming, land ownership, commons and family relationships. He conducted research in Nagano Prefecture with students (Kawashima and Watanabe, I944) who later came to be involved in the creation and development of the JASL (Kawashima, I978).

\section{The post-war foundation of the sociology of law 21}

Soon after the end of World War II, young legal scholars conducted empirical research in villages of peasants and fishermen. ${ }^{22}$ Sociological studies of law were now clearly distinguished from ordinary

I8 Social norms that people would describe as 'traditional customs' to the researchers could be different from the social norms that people actually complied with, because 'traditional customs' could in fact have been transformed into something new, particularly through statutory provisions in North China and the political influences of the Communist Party and others.

I9 The research was conducted in co-operation with the Manchurian Railway Company and was criticised in that it would help Japanese colonialism in China, though the research itself was said to be purely academic. There was further criticism about the quality of the data collected, in that Chinese people under Japanese occupation would not have told the truth to Japanese researchers.

20 Kawashima later recalled that he began to develop his interest in the sociology of law when he went to Manchuria and observed gaps between Chinese Civil Law and the local customs of the five ethnic groups living in the region (Kawashima, I978).

2 I The JASL has as members not only legal sociologists but also legal psychologists, legal anthropologists, legal ethnographers, etc. In this sense, the sociology of law is taken to mean all social sciences of law in Japan. This paper deals mainly with legal sociology, but includes legal psychology to the extent that it is relevant to Kawashima's work.

22 The pre-war family law adopted the family model of the pre-modern swordsmen class, in which a male filial line was considered crucial and the eldest male, until retired, was given power over family members. Research 
legal scholarship, and no longer accepted a subordinate role to legal scholarship. At the same time, reflecting the political enthusiasm for democracy of the time, it was expected that empirical findings were not to be used to justify the undemocratic values lingering in post-war society but to overcome them and advance democracy under the new Constitution. ${ }^{23}$ Even if standpoints differed widely among scholars from Marxist to Weberian theorists, it was this pro-democratic enthusiasm that explains why the sociology of law attracted so much academic attention, which resulted in the creation of the JASL soon after World War II. ${ }^{24}$

But it was Kawashima who changed the whole landscape of the sociology of law in Japan at this time. He taught civil law and did research in particular on the law of ownership. Kawashima still relied on Ehrlich, not only in criticising the German-style legal scholarship prevailing in Japan (Kawashima, I95Ia), but also in conducting empirical research on living law. ${ }^{25}$ However, he turned the pre-war scheme of Ehrlich upside down and emphasised the necessity for social change. When Suehiro and others tried to find living law in pre-war Japan, they tried to 'learn' from living law so that they could interpret and apply legal statutes in a manner to fit them to the social reality of the time. ${ }^{26}$ Kawashima believed in the need for a new constitutional law, and worked with the drafting of a new Constitution and the new rules of family law in mind. ${ }^{27}$ Despite facing the persistent attitudes of traditionalists, he strongly advocated changing the living law of pre-war Japan. ${ }^{28}$ His papers on Japanese legal consciousness were written under these political and social circumstances, ${ }^{29}$ though their theoretical implications went far beyond the contemporary circumstances.

Less than a year after the end of the war, Kawashima published an uncompleted paper in which he contrasted the traditional Japanese normative consciousness with the modern legal consciousness in the West (Kawashima, I946a). $3^{\circ}$ He argued that Japanese people widely failed to comply with economic regulation law even during the war, because the law required, in order to function, a

on a rural village was often conducted to find 'living law', which had a different type of marriage and inheritance, showing that the family model prescribed by the pre-war family law was not universal in Japanese society (Nakagawa, I95I).

23 This was described as an unspoken understanding among JASL members (Ushiomi, I95 I, pp. I93-94).

24 It was Kawashima who initiated a plan to found the JASL. Kawashima later recalled that he initiated the plan to establish the JASL with Susumu Isoda. Kawashima explained that he wanted to establish the JASL as a forum to discuss with academics at other universities, which was rather rare in Japan at that time (Kawashima, I978, p. 236). Because of this historical origin and the pro-democratic orientation, the JASL has a tradition of liberal association.

25 Kawashima also reported a type of marriage in a fishermen's village, which was different from the one dominant before the war (Kawashima, I957, Part II).

26 Ehrlich's arguments on living law and legal provision can be understood to provide a scheme of legal development from living law to legal provisions through the activities of legal professionals (Ehrlich, I936, Chapter 8). Law professors tried to participate in this process of legal development.

27 He sat on the special committee for judicial reform as a subordinate to the committee members. He listened to committee members who tried to maintain the imperial system and the old family law, which he believed apparently differed from the desire for democracy among the Japanese people (Kawashima, I978, pp. 2 I I20, 227-29).

28 Ehrlich himself argued for the use of legal provision as a means of social change (Ehrlich, I936, pp. 202-03). Such a perspective co-existed with a developmental perspective in Ehrlich's arguments as noted in footnote 26.

29 Kawashima wrote papers criticising the traditional ideology of piety and others and published them in nonacademic journals, for instance, Kawashima (I950). This was written to criticise Eiichi Makino, a well-known senior scholar in criminal law, who tried to defend a filial relationship based on piety (Makino, I950). The debate was over how to interpret a provision of the post-war family law. 
modern legal consciousness, which Japanese people did not have. He strongly urged Japanese people to make the modern law epitomised in the post-war Constitution 'our living law', in order to democratise Japan. In this and a later revised paper, Kawashima presented a model of 'modern legal consciousness', drawing upon the Kantian notion of morality with specific reference to the categorical imperative. ${ }^{3 \mathrm{I}}$ Concerning the Japanese pre-modern normative consciousness, Kawashima presented the social relationships between tenants and landlords in farming and housing as social conditions that bred the traditional consciousness, ${ }^{32}$ while pointing out differences between the modern law and the Japanese consciousness in such legal areas as ownership, contract, family, public law and international law.33 During the I940s and I950s, he devoted himself to critically analysing traditional social norms in relation to their social backgrounds (Kawashima, I946b, I95 Ib, I95 Ic, I957).

Kawashima continued to write on incongruities between the institution of law, in particular litigation, and the Japanese legal consciousness. The best-known article in English is 'Dispute Resolution in Contemporary Japan' (Kawashima, I963) and the one in Japanese is Nihonjin no Ho Ishiki [Japanese Legal Consciousness] (Kawashima, I967). ${ }^{34}$ However, in these works, the focal point of argument clearly changed from the normative to the empirical. He compared the US and Japanese statistics of litigation cases in traffic accidents and argued that the Japanese pre-modern normative consciousness was a much more important cause of the small number of litigation cases than the cost and delay of litigation.

His empirical argument proved to be more controversial than his normative one, inviting criticism from Japanese and foreign scholars, as we will see in the next section. Although the phrase 'legal consciousness' was used as a direct translation of the Japanese words Ho Ishiki in the English translation of his argument on contract (Kawashima, 1974), Kawashima did not use the words 'legal consciousness' in his own English article. He later pointed out that the English words 'legal consciousness' were misleading, as he meant to include the subconscious as well as the conscious. He also noted that his idea of legal consciousness, Ho Ishiki, presupposed a theoretical framework of cultural sociology or anthropology, but included psychological elements such as emotional/affective response, desire/volition and value judgment (Kawashima, I972C, pp. 403-05).35

3I The modern legal consciousness consists of two elements: (I) each individual has the sense of having his/her own territory and recognises that all other individuals also have their own territories; and (2) unconditional voluntary compliance with the law. Explaining the first element, he emphasised a sense of individual equality as a moral person in legal relations. Kawashima presented the normative framework to critically analyse empirical phenomena. He later noted that the idea of legal consciousness used in these papers meant a 'structure of ethos' of the people. He also wrote that the paper was not about the sociology of law, but about social philosophy (Kawashima, I972C, pp. 403-05, 4II).

32 Here, Kawashima offered an image of tenant farmers who did not have a sense of equality with their landlords as a typical example of a pre-modern social relationship. But one might ask to what extent the image of tenant farmers reflected their realities after World War I, when there were labour and tenant farmer movements despite the unfavourable legal situations (Vanoverbeke, 2004).

33 As a professor of property law, Kawashima wrote an influential book on how the traditional Japanese idea of property ownership differed from the idea of modern Western property ownership. He used a model of modern property ownership based on German law to show how Japanese practice was not modern. He started this work as a special lecture on property law before World War II (Kawashima, I949). Although this work was just on property ownership and was apparently influenced by Marxist ideas, his perception of Japanese normative practice seemed to be formed while working on this study. In this sense, this anticipated his arguments on the Japanese normative consciousness.

34 The Japanese book was based on his lectures for the general public. An earlier version of the book was published as a paper in a monthly journal (Kawashima, I966).

35 In the Japanese book, Kawashima explained his idea of legal consciousness as containing (I) perception of law and its framework, (2) value judgment of law and its framework, and (3) emotion towards law, including emotional attitudes (Kawashima, I967, p. 8). 
However, Kawashima wrote about not only the Japanese pre-modern attitudes but also the social structure that supported such attitudes (Kawashima, I960). He seemed to believe that subsequent social changes brought by further industrial urbanisation would produce a transformation of the Japanese legal consciousness and eventually an increase in litigation. ${ }^{36} \mathrm{He}$ considered that there were various factors which would influence the legal control of a society and that consciousness was not the ultimate fundamental determining factor of legal phenomena. But he argued that the reason for focusing on legal consciousness was that legal consciousness not only affected lawrelated behaviour, but also was the factor closest to law-related behaviour among relevant factors (Kawashima, I967, pp. I0-I4). Crucially, Kawashima argued that legal consciousness was the most powerful predictor of legal behaviour, but that legal consciousness had a social foundation and would change as its social foundation changed (Kawashima, I967, pp. I97-203).

Kawashima taught at Stanford University for a year in 1958-59, and after this became increasingly interested in social scientific studies in the US. 37 He not only followed the development of socio-legal studies in the US, $3^{8}$ but also expanded the theoretical horizons of the sociology of law in Japan extensively. After he retired in 1970, he began to practise as a private attorney, but he continued to make efforts to open up Japanese sociology of law to foreign scholars, 39 and also other fields of social sciences.

It was his notable achievement that he edited a series of ten volumes of Ho Shakaigaku Koza [Lectures on the Sociology of Law], published from I972 to I973. This series was not a collection of readings, but of original articles. It covers virtually all areas of the sociology of law: Volume I about the formation of the sociology of law, including nineteenth-century scholars in law, sociology, anthropology, economics, political science and psychology; Volume 2 about the present situation of the sociology of law in foreign countries from the US to European and socialist countries, and in pre-war and post-war Japan; Volumes 3 and 4 about the theoretical and methodological foundations of the sociology of law, including methods of social research, social system theory and Kawashima's model of law as the focal point in the sociology of law; ${ }^{40}$ Volumes 5 and 6 about law and dispute resolution, mainly including various theoretical approaches to adjudication and non-judicial decision-making processes; Volumes 7 and 8 about society and law, including Marxist and Weberian theories, the relation between living law and statutes in various legal fields in Japan, such as commons, land inheritance and labour, and the impacts of law and

36 In the English paper, Kawashima mentioned changes of attitude towards asserting rights shown by surveys conducted by the Ministry of Labour in I 950 and by the National Public Opinion Survey in 1952 (Kawashima, I963, pp. 58-59). In the Japanese book, he cited the decrease of conciliation cases as evidence of a change in this consciousness. He also referred to the results of Sasaki's research on legal attitudes conducted in a rural prefecture, Shimane, and an urban centre, Osaka (Sasaki, I967, p. 88). The use of the court was preferred more in Osaka as compared to Shimane (Kawashima, I967, p. I83).

37 Because of World War II, Kawashima could not study abroad in his younger years. He went to the US for the first time in 1950, which was his first trip to a foreign country. He stayed there for three months and attended a lecture by Talcott Parsons at Harvard University (Kawashima, I978, pp. 217-18).

38 He recalled that scholars were indifferent to the sociology of law in the US when he visited for the first time in I950, finding that the sociology of law was taught only at the University of Wisconsin (Kawashima, I978, p. 2I7). But later he observed that socio-legal studies in the US were advancing so quickly that Japanese scholars might not be able to follow (Kawashima and Ishimura, 1964). In the US, the Law and Society Association was founded in 1964 .

39 His efforts led to the annual conference of the International Sociological Association Research Committee on Sociology of Law (RCSL) in Hakone, Japan, in 1975. The RCSL was founded in 1972.

40 Kawashima argued that if the sociology of law is a distinctive field of academic study, it must develop a sociological theory to deal with the law itself, indicating that sociological studies of the legal profession fall in the sociology of profession or occupation, but not in the sociology of law (Kawashima, 1978, pp. 284-85). 
legal institutions upon society; and Volumes 9 and Io about history, culture and law, starting from primitive and archaic societies to traditional societies and their modernisation, and finally contemporary societies in Europe, socialist countries, Asia and Africa.

A large number of scholars not only in law but also in the social sciences and humanities contributed to the series. Kawashima intended to show the sociology of law as an interdisciplinary science to students and scholars in both law and the social sciences. His intention was well served by the series that clearly expanded the horizon of the sociology of law in Japan, far beyond the study of living law.

\section{The rise of the sociology of law as empirical social science}

While Kawashima followed the rapidly growing literature of social scientific studies of law in the US and Europe in the I960s and I970s, young scholars began to conduct empirical studies inspired by studies in the US and Europe. It is also during this period that various areas of law became objects of empirical studies, though fieldwork to study living law in rural villages and also in farming areas in urban suburbs continued as the tradition of the sociology of law.

Scholars who played significant roles in the post-Kawashima period were Kahei Rokumoto and Takao Tanase, who both started their academic careers under Kawashima. Rokumoto was the successor of Kawashima for the chair of the sociology of law at the University of Tokyo and, while advocating and conducting empirical studies, introduced foreign sociological theories of law, such as those of Niklas Luhmann and Philip Selznick, into Japan (Luhmann, I977; Nonet and Selznick, I98I). Rokumoto was also the first scholar who taught only the sociology of law, but no other subjects in law. Takao Tanase also worked heavily in the field of civil justice. He was a theorist rather than an empirical researcher, though he conducted some empirical research in the US (Tanase, I983, I992, 2003).4I Tanase taught the sociology of law at Kyoto University but also worked on issues of the civil law (Tanase, I994, I999).42 Kawashima's arguments on the Japanese legal consciousness have had an enduring impact upon subsequent empirical studies, particularly in the field of civil justice, but as empirical studies in the field of the sociology of law increased, themes and perspectives diversified.

\section{The use of law and access to the legal machinery: the continuity of Kawashima's theme}

Though Kawashima maintained his normative model of law, he later integrated it into a comprehensive model of law in his search for the distinctively legal.43 $\mathrm{He}$ emphasised adjudication as the focal part of the distinctively legal. But empirical research on adjudication itself has scarcely been conducted since. ${ }^{44}$ Rather, it was Kawashima's arguments on legal

4I Some of his works are translated into an English book (Tanase, 20I0).

42 He also translated Jerome Frank's Law and the Modern Mind (Frank, I974).

43 Kawashima presented two theoretical models of law: a structural model of law and a functional model of law. Concerning the structural model, he conceptualised law as a system of double social control, partly relying on the Weberian concept of law in which the role of enforcement is differentiated. According to Kawashima, a group of people specialising in imposing sanction is also controlled by normative information. A typical example is adjudication. This double structure of social control is unique to the law and must be the focus of research in the sociology of law (Kawashima, I972a). Concerning the functional model, Kawashima focused on adjudication as a distinctive way of dispute resolution. According to Kawashima, adjudication has three social functions: first, through adjudication, order of reason is distinguished from order of force; second, distinctively legal norms are differentiated from other social norms; third, social control of members of a society is by control of adjudication in dispute resolution (Kawashima, I972b).

44 Kawashima referred to research on judicial behaviour in the US as an example (Kawashima, I972b, pp. I I-I2). But behaviouristic research was not pursued in Japan, because it was too difficult to get access to the judiciary for the purpose of empirical research and also because behaviourism was not well accepted among legal 
consciousness which foreshadowed the enduring concerns of Japanese scholars with comparing law and practice as well as contrasting Japan and the West.

Kahei Rokumoto applied Kawashima's normative scheme to the legal resolution of civil disputes, and conducted an interview survey in Tokyo in 1968.45 He found that the social changes of Japanese society had increased demand for legal services, which was often satisfied by pseudo-lawyers, and that the use of formal legal machinery seemed determined by one's occupational position and particularistic social networks (Rokumoto, I97I).

Rokumoto also worked on the empirical aspect of Kawashima's argument. Ever since Kawashima made his argument about Japanese legal consciousness, one of the challenges has been how to measure legal consciousness (Miyazawa, 1987). How we could understand the relationship between Kawashima's normative model and empirical model also seemed to remain a question. It is difficult not only to identify what the legal consciousness is, but also to operationalise it in order to measure it empirically. Rokumoto refined the concept of legal consciousness into a narrow sense of legal consciousness, on the one hand, and legal conception, on the other. The former consists of three elements: knowledge about law, attitudes toward law and opinions about law; while legal conception is a framework to perceive law. ${ }^{46}$ Rokumoto explained that the narrow sense of legal consciousness would be the 'general sense of justice' in English, more or less the equivalent of KOL (Knowledge and Opinion about Law; Podgorecki, Kaupen, van Houtte, Vinke and Kutchinsky, 1973), while the legal conception would be the 'idea of law' or 'Rechtsvorstellung' (Rokumoto, I986, p. I96). The point of the distinction between the narrow sense of legal consciousness and legal conception is that the former can change for a rather short period of time, while the latter tends to persist. Rokumoto argued that the Japanese normative conception 'giri' was the ordering principle of pre-modern Japanese society and formed the founding element of Japanese legal culture (Rokumoto, I986, pp. 2I5-I6, 22I-3I, 2004, pp. 29-30). 47

Though not based on Rokumoto's framework, surveys of opinions and attitudes about the law have been conducted several times since the I970s (Nihon Bunka Kaigi, I973, I982; Kato, Fujimoto et al., 2003; Kato and Fujimoto, 2006).48 The surveys of Nihon Bunka Kaigi tried to measure characteristics of Japanese legal attitudes and found that respondents tended to have little interest in laws, expect flexible applications of legal norms, and split into punitive and

sociologists in Japan. Behaviouristic research on judicial process in the US was introduced in Japan in the I960s (Hayakawa, I966).

45 The research was the first survey on legal problems and problem-solving behaviour, focusing on traffic accidents and housing disputes in Japan. The theoretical framework of this research was published in English (Rokumoto, I972, I973).

46 The three elements of legal consciousness in the narrow sense remind us of Talcott Parsons' action theory, which defined three categories of action orientation: cognitive, cathectic and evaluative, while 'legal conception' reminds us of Weltanschuung, a cognitive framework to view a world.

47 'Giri' is a pre-modern obligation, the content of which was diffuse, as there existed no effective enforcement mechanism except shame. A person who had an obligation was expected to figure out what s/he should do and to do it without a demand for performance. Rokumoto argued that 'giri' survived social changes after the Meiji Restoration and continued to influence Japanese society (Rokumoto, I 986, pp. 222-23, 227). Kawashima argued that (I) 'giri' existed in particular social relations that were not temporal but enduring, (2) a 'giri' relation involved a comprehensive life relation, (3) a particular 'giri' was born in relation to one's social position without any intention, (4) it occurred in personal, often face-to-face relations, (5) it was based on an emotional bond, and (6) it reflected the hierarchical nature of social positions (Kawashima, I95IC). Kawashima seemed to expect that 'giri' would wither away as social mobility and functional differentiation increased.

48 Nihon Bunka Kaigi conducted a survey twice during the I970s. The population of these surveys were residents of the Tokyo Metropolitan area. Masanobu Kato directed a multinational survey in twenty-two countries and regions in which respondents were university students in law and management/commerce in the I990s. 
lenient groups. These findings were understood to support the view that Japanese people have attitudes towards the law that are different from the West. ${ }^{49}$ In contrast, Masanobu Kato suspected that anecdotal episodes that Kawashima used as examples to show distinctive Japanese legal attitudes were misleading (Kato, Fujimoto et al., 2003, pp. 5-6), and did not find peculiarly Japanese attitudes towards contracts in their international survey results (Kato and Fujimoto, 2006).

The latest survey of Japanese legal attitudes was conducted in 2005 as a part of a large research project, The Civil Justice Research Project. The survey asked about legal attitudes and knowledge as well as social attitudes towards norms and disputes..$^{\circ}$ It also replicated the survey of Nihon Bunka Kaigi almost thirty years later. They found that Japanese attitudes had not changed significantly except for becoming more punitive (Matsumura et al., 2007c). However, full analyses of the survey results are yet to come.

Scholars who studied under Rokumoto or Tanase also addressed the issues Kawashima raised, but findings differed. Ichiro Ozaki, in his research on disputes among residents in eleven condominiums in a residential district of Yokohama, found that disputes tended to deteriorate to emotional exchanges, without much possibility of communication based on reason (Ozaki, I996). But Kiyoshi Hasegawa conducted fieldwork on private agreements among residents, also in Yokohama, and found that residents could behave as rational actors who used the law in a reasonable way in their attempts to preserve residential environments (Hasegawa, 2006). Yoshitaka Wada, based on his research on disputes between tenants and house owners, argued that the meaning of dispute resolution had been changing in urban society from restoring harmonious relations to handling immediate disputes while letting a conflicting relation continue, and found that people mobilised the law as a strategic weapon to pursue their selfinterests (Wada, I982). Masaki Abe conducted field research on how local residents invoked the law for the purpose of environmental protection and found a similar tendency to that found by Wada: people mobilised the law as one of the instruments available to achieve their purposes (Abe, 2002).

These four studies were conducted as qualitative research to contribute to both empirical and theoretical understandings of the use of the law, rather than identifying overall patterns of behaviour in Japanese society. Ye, these studies seemed to show that the actual behaviour of Japanese people could be different from and more varied than that which Kawashima described in his empirical arguments. They also seemed to limit the validity of his normative arguments.

It would be fair to note here that Kawashima's empirical arguments of legal consciousness began to be directly and frequently critically assessed by foreign as well as Japanese scholars from the late I970s. The central issue of the debate was whether the Japanese normative consciousness was the main cause of a small number of litigation cases, though the theme was not always shared and the way of conceptualising the issue was different among scholars (Haley, I978, I99I; Oki, I983; Upham, I987; Ramseyer, I990; Tanase, I990; Wallschaeger, I997; Rokumoto, 2004).

The Civil Justice Research Project (2003-2008), directed by Masayuki Murayama, conducted three kinds of nationwide research to cover the whole process of problem-solving behaviour, from experience of a problem to the use of litigation. The first survey, the Disputing Behaviour Survey,

49 They partly relied on Kawashima (1967) to make specific questions in the questionnaire (Nihon Bunka Kaigi, I973, p. 36).

50 The survey was directed by Yoshiyuki Matsumura, a legal psychologist, who was the last scholar who had started an academic career under Kawashima before he retired. Matsumura et al. apparently assumed that Kawashima's idea of legal consciousness in his empirical argument indicated psychological attitudes towards law (Matsumura et al., 2007a, 2007b). 
consisted of a Consciousness Survey, which was discussed above, and a Behaviour Survey that enquired into problem experience and subsequent behaviour. The second survey, the Advice Seeking Behaviour Survey, focused on how people sought advice from various agencies and how they evaluated it. The samples of these surveys were randomly chosen from among Japanese people from twenty to seventy years old. The third research, the Litigation Behaviour Survey, took data from randomly chosen litigation cases at the district courts and then asked questions of the litigants and their lawyers..$^{5}$

The Disputing Behaviour Survey found little evidence to support the perception that Japanese people experienced few legal problems and that they were reluctant not only to make claims but also to reject claims. Patterns of behaviour in these early stages of problem-solving were surprisingly similar between Japan and the US, and significantly affected by the types of problem that people experienced. These findings raise questions about Kawashima's presumption that legal consciousness defines disputing behaviour and, even if legal consciousness did matter, to what extent and how it mattered concerning behaviour.

The Litigation Behaviour Survey found, contrary to the popular view, that litigants were less satisfied when litigation ended in settlement than when litigation ended in judgment (Foote and Ota, 2010, p. 228).52 The survey further obtained interesting findings about gaps in perception between litigants and their lawyers. ${ }^{33}$ Apparently these findings indicate that behaviour more closely related to the formal legal system tends to be shaped by institutional circumstances internal to the formal legal system.

The Civil Justice Research Project was carried out by more than thirty scholars, including some sociologists who did not have legal backgrounds. During the period of this project, and also afterwards, similar and other types of research, such as qualitative interviews and Internet surveys, were also conducted by members of the Project, though only partial initial findings have been published so far (Tamaki, Maeda, Sugino, Minimikata and Murayama, 2009; Maeda, 2009). Such a large-scale research project could be done because general interest in empirical evidence about the function of the civil justice system increased as the Justice System Reform proceeded. The final report of the Justice System Reform Council declared that it was the purpose of the series of reforms planned by the Council that the rule of law would be firmly established in every corner of Japanese society. This was a clear and significant break away from traditional policy since the Meiji era that laws should be learned and followed only as Western techniques.54 Around the turn of the century, empirical studies with a policy orientation began to be conducted, though those studies also tried to answer theoretical questions. The Civil Justice Research Project was an example of such a study. Another is the research on how litigants evaluate their experience of litigation. The purpose of the research was in many ways similar to consumer satisfaction research, but it was designed by a legal psychologist, Ikuo Sugawara, to obtain data on theoretical questions of procedural justice (Sugawara, Yamamoto and Sato, 2010).

5I Findings of the Civil Justice Research Project were published in three volumes (Matsumura and Murayama, 2010; Kashimura and Bushimata, 2010; Foote and Ota, 2010) and in some papers (Murayama, 2007; Abe, 2009; Foote et al., 2009).

52 Kawashima assumed that settlement in litigation reflected a choice of the litigant and that a large percentage of settled cases indicated the influence of Japanese legal consciousness. He argued that judges advised litigants to settle, responding to litigants' expectations (Kawashima, I967, pp. I5I-53).

53 For instance, lawyers who represented parties were more willing to settle than their clients, and lawyers were also more sensitive to the judge's suggestion to settle (Foote and Ota, 20Io, p. I95; Moriya, 20II). 


\section{Criminal justice}

In the field of criminal justice, Kawashima did not publish an article or book, though he planned to write a chapter in his Japanese book on Japanese legal consciousness. The manuscript was discovered after his death, as we will see later.

It was Ryuichi Hirano who played a significant role in promoting empirical studies of criminal justice. German legal doctrine dominated the field, but Hirano was one of the first legal scholars who studied in the US after World War II. Though he did not conduct any empirical research by himself, he helped the development of sociological jurisprudence in the field of criminal law, paying attention to actual practice in the construction of legal doctrines. 55 He tried to introduce adversarial procedure into the Japanese criminal justice process, criticising the inquisitorial aspects of the Japanese criminal procedure. ${ }^{6}$ In his later years, he diagnosed the Japanese criminal trial, which he saw as a forum for ascertaining the defendant's guilt rather than deciding whether a defendant was guilty or innocent. He concluded that it would be hopeless unless a drastic reform such as the introduction of a jury or an assessor's system could be implemented (Hirano, I985). The latter of these was later realised as the Saiban'in Seido, the lay judge system, by the Justice System Reform. Hirano's criticism of the Japanese criminal justice system reflected a common concern of criminal law scholars with how to locate the Japanese system between the pre-war European continental tradition and the post-war American adversarial ideal.

Social scientific research on criminal justice began in the field of police studies. The first research in this field was made by Setsuo Miyazawa, who observed detectives' work and conducted a questionnaire on crime investigation in Sapporo (Miyazawa, I985). 57 He relied on Amitai Ezioni's theory of organisation and found that detectives' involvement in their work was mainly calculative and that they sought proactive investigation activities, trying to interpret the law for the interest of law enforcement, because the organisational control of achievement evaluation emphasised the clearance of cases.

Masayuki Murayama conducted the second empirical study on the police, observing uniformed police activities at police boxes and in patrol cars in Tokyo (Murayama, I990). He found that the police put strong emphasis on law enforcement, while their routine work was mostly about the maintenance of order. Because of the discrepancy, cases that were often serious for ordinary people were not handled adequately. The emphasis on law enforcement resulted from the occupational and organisational interests of police officers, based on their self-esteem and desire for promotion..$^{8}$

During the I970s, when the fieldwork on the police was conducted, a comparative survey on responsibility was also conducted in Detroit in the US and Yokohama in Japan (Hamilton and Sanders, I992; Ishimura, Tokoro and Nishimura, I986). This can be seen as a survey on Japanese normative consciousness in the field of criminal justice, but the design and method of research were much more sophisticated than those of the Japanese legal consciousness studies conducted in the early I970s, as the former used experimental designs which would be more frequently adopted in later surveys designed by psychologists (Matsumura, 2007b) and game theorists

55 Hirano was a member of Study Group of Empirical Legal Scholarship organised by Kawashima. Rokumoto and Matsumura were members of the group.

56 His textbook on criminal procedure was known for its interpretation of the law from an adversarial point of view (Hirano, I958).

57 The work was later translated into English (Miyazawa, I992).

58 Murayama's finding was not congruent with a common view of Japanese police in the US that the Japanese police was a model of community policing, emphasising crime prevention (Bayley, I976, revised edn, I99I). Bayley aimed at advocating for a change of the policing policy dominant in the US by presenting the Japanese case as an example of community policing. 
(Ota, 2009). Hamilton and Sanders found two images of the responsible actor, a stranger in the US and a friend in Japan. They argued that visions of responsibility and justice were shaped by variations in the hierarchy and solidarity of everyday social life, and presented two configurations, equality and low solidarity in the US and authority-subordination and high solidarity in Japan (Hamilton and Sanders, I992, p. 203).

In the early I990s, Murayama returned to the same police station to see how changes of policing policy affected routine police activities (Murayama, I996). Murayama also conducted questionnaire surveys and interviews on the criminal defence practice of lawyers and found that most courtappointed counsel assumed the guilt of defendants, following the inquisitorial model of defence rather than the adversarial (Murayama, 2002).

After Kawashima passed away in I992, a handwritten manuscript of Chapter 6 on 'Consciousness on Crime and Punishment' was found among his writings (Kawashima, n.d.). ${ }^{99}$ In this manuscript, Kawashima pointed out two characteristics of the Japanese Penal Code: very broad definitions of crimes and very broad scope of punishment, that is, a wide range of discretion given to judges in deciding what would constitute crime and what punishment to be imposed upon it. These characteristics, Kawashima argued, were in stark contrast to Western penal law that had more detailed definitions of crime and punishment. He considered that Western legal consciousness demanded clear and fixed definitions of crime and also a clear and fixed relationship between crime and punishment, whereas Japanese legal consciousness saw evaluation of crime and punishment as flexible and did not accept a fixed relationship between crime and punishment. According to Kawashima, such contrasting differences in legal consciousness are also reflected in differences in law enforcement practice in Japan and the West: policemen usually condone traffic violations and prosecutors exercise wide discretion in Japan, while policemen enforce the law mechanically in the West. ${ }^{60}$

As this manuscript was found after his death, it did not influence the development of the empirical studies of criminal justice we saw above. But it clearly shows that Kawashima had a strong presumption that a certain legal consciousness was shared among the Japanese and that it must have defined patterns of behaviour also in criminal justice. However, in the manuscript, he also argued that it was important to distinguish the consciousness of the ordinary people and the consciousness and behaviour of those in political power. But he somehow abandoned this line of argument and went on to write on the legal consciousness of the ordinary people.

Retrospectively Miyazawa's and Murayama's studies of the police focused on aspects of the consciousness and behaviour of those in political power. These studies indicated that the occupational and organisational interests of police officers are crucial in explaining police behaviour. Both Miyazawa and Murayama did not notice the cultural tendencies in police behaviour that Kawashima presented as Japanese characteristics. These police studies indicate that the ways in which law enforcement behaviour is institutionalised are much more significant in shaping their behaviour than the consciousness of the ordinary people.

Foote (I992) presented an excellent description of the official view of the exercise of their power, which he characterised as benevolent paternalism. This study shows another aspect of what Kawashima called the consciousness of those in political power. It seems clear that what

59 A copy of the manuscript is filed with the author. The original is filed in the Kawashima Collection, Sapporo University Library. The manuscript is titled 'Chapter 6: Consciousness on Crime and Punishment', and classified as No. 295 of the books written by Kawashima in the catalogue (Sappro Daigaku Toshokan, 1995). I thank Sapporo University Library for allowing me to read the manuscript. I also thank Yoshiyuki Matsumura and Noriko Hashiba for helping me obtain a copy of the manuscript.

60 His anecdotal personal experiences seem to be far from convincing, though limited space does not allow further discussion. Prosecutorial discretion seemed to start in early Meiji, in order to reduce the budget for confining prisoners (Mitsui, I970, pp. 910-I4). 
Kawashima described as Japanese characteristics were those of a patriarchal criminal justice system. ${ }^{61}$

These developments in research in criminal justice indicate complexities of different kinds of consciousness and the limited effects of the ordinary people's consciousness upon official behaviour. As we saw in civil justice, ordinary people and officials of a justice system have different perceptions of the law and the legal system. Future research would address issues of how, to what extent, and in what context legal consciousness matters in shaping official behaviour and the behaviour of ordinary people.

The Saiban'in Saiban, trial by six lay assessors and three professional judges, is an institutional forum where the consciousness of ordinary people meets that of legal professionals ${ }^{62}$ As lay assessors are prohibited by law from talking, research on Saiban'in Saiban has mainly focused on public attitudes on the new institution. Matsumura et al. conducted a survey before and after the lay judge system started, to examine public attitudes towards the Saiban'in Saiban and criminal justice to see how they changed after the system began to work in 2009 (Matsumura, Kinoshita, Ota and Yamada, 2008, 2012). Simple descriptive findings have been reported so far. ${ }^{63}$

\section{The legal profession}

Zensuke Ishimura introduced US-type empirical studies of the legal profession to Japan in the I96os (Ishimura, I966, I969). But it was Kahei Rokumoto who conducted the first nationwide survey of Japanese lawyers in I98I. This was a project of the Japan Federation of the Bar Associations (JFBA) to better understand the legal practice and financial situation of Japanese lawyers (Nihon Bengoshi Rengokai, Bengoshi Gyomu Taisaku Iinkai, I98I).64 The JFBA has repeated the nationwide survey every ten years since then and the data give us a good overview of how the Japanese legal profession has or has not changed in various aspects of their practice. ${ }^{65}$

The enactment of the law in 1986 that allowed foreign lawyers to practise in Japan ${ }^{66}$ prompted the expansion of Japanese law firms, though their size was still limited by the small population of lawyers. ${ }^{67}$ The Justice System Reform brought a series of changes to expand legal services in Japan.

6I Murayama characterised Japanese criminal justice as lenient but intolerant, allowing a wide range of discretion and flexible applications of procedural rules (Murayama, 1992). The ideal of paternalism goes back to the pre-war official ideal shared by the high-ranking officials who worked for the national government. They regarded people as a flock of sheep and themselves as shepherds who took care of the flock by deciding what was good for the sheep. As Kawashima himself emphasised, patriarchy was not despotism but it did patronise (Kawashima, I963, p. 43).

62 This body decides on guilt and sentence in the trials of certain serious cases. The Supreme Court conducted questionnaire research of Saiban'in and candidates and published it every year (Saiko Saibansho, 2009, 2010, 20II, 20I2).

63 Statistical analyses, including comparison between 'before' and 'after', have still to be done. The data indicate that, after four years, many people knew about the lay judge system, but people's attitudes towards the duty of serving as a lay judge did not seem definitely positive or to have become more favourable. The statistical significance of these findings has still to be published.

64 A part of the findings was published in an English paper by Rokumoto (I988).

65 The response rate significantly decreased over the decades, particularly among urban lawyers, which raises a serious question about the representativeness of the response group.

66 Gaikoku Bengoshi ni yoru Horitsu Jimu no Toriatsukai ni kansuru Tokubetu Sochiho [Special Statute Concerning Foreign Lawyers to Handle Legal Matters], Act No. 66 of 1986.

67 The increasing business orientation of the US legal profession and the effects of the globalising economy seemed to bring more critical views on the structure of the Japanese legal profession. For instance, Tanase criticised the rigid regulation of the bar over legal practice and argued for expanding legal services for ordinary people (Tanase, I987). 
But the reforms were implemented with the grudging consent of the JFBA, as lawyers argued that there would not be enough need for lawyers. In this way, Kawashima's empirical argument overshadowed the reform process from its beginning.

To increase the number of lawyers, professional law schools were established in 2004. The new bar examination began in 2006, which graduates of the new law schools took to become qualified as lawyers. The number of newly registered lawyers, including judges and prosecutors, increased from around 500 during the I990s to I,000 in the early 2000s, and 2,000 from 2007. Given the increase of lawyers, law offices began to expand their practices (Hamano, 2007), and the largest law office now has about 500 lawyers. At the other end of legal services, the Ministry of Justice established the Japan Legal Support Center in 2006, which provides legal aid both for civil and criminal cases. It also established local offices in every prefecture where free legal advice is given to the indigent. ${ }^{68}$

How much these changes affected the structure of the legal profession can be traced by the results of the JFBA surveys. Although lawyers in Tokyo began to show some changes in their practice, typically, by increasing work on non-dispute cases, there were few significant changes before the turn of the century: about half of Japanese lawyers worked alone; 80 per cent or more of the lawyers worked at offices where fewer than four lawyers worked together; about half of the clients were first-time clients. However, significant changes began to occur in the 200os. Only 34 per cent of lawyers worked alone in 2010.69 The percentage of lawyers who worked at offices with twenty or more lawyers increased from I per cent in 2000 to 9 per cent in 20I0. The percentage of firsttime clients also increased from 52 per cent in 2000 to 60 per cent in 20I0. These changes were most salient in Tokyo (Nihon Bengoshi Rengokai, I99I, 2002, 201 Ia).

Empirical research on legal services and the legal profession has been conducted since significant changes in the legal profession, albeit small at the time, began in the I99os. Ryo Hamano conducted interview research on legal practice for corporations in Tokyo in the early I 990 os and found that there would be a large latent demand for legal services, particularly among smaller companies (Hamano, I993-94). Murayama et al. conducted nationwide research on legal advice provided by bar associations, in co-operation with the Japan Federation of Bar Associations, in 2007, and found that social distance and concern with the lawyer's fee would deter the public from visiting lawyers (Murayama, 2009, pp. I85-90; Murayama et al., 2010). More recently, Miyazawa directed a survey of lawyers, to compare the specialisation and stratification of the legal profession between Japan and the US in 2008, drawing upon the findings of Chicago Lawyers (Heinz and Laumann, I982; Heinz, Nelson, Sandefur and Laumann, 2005). The survey found that the traditional way of lawyering, with individual and small company clients, was prevalent nationwide, but that, in Tokyo and Osaka, a rather small segment of younger generation lawyers specialised in corporate clients. The survey also found an advancement of female lawyers into the field of corporate business law as well as family law (Miyazawa et al., 20Io; Miyazawa, Bushimata, Ishida and Ageishi, 20II; Miyazawa, Bushimata, Fujimoto and Ageishi, 20I2). Hamano's and Murayama et al.'s research was concerned with the needs of legal services, starting from the underlying question of why there was a small number of lawyers in Japan. In this sense, these studies shared a concern with the issue Kawashima raised in his arguments on the Japanese legal consciousness.

68 Legal representation for the indigent is not free in Japan, though legal advice is.

69 The JFBA began to publish a White Paper on the Lawyers in 2002, which gave the distribution of lawyers according to the size of a law office. The percentage of solo practitioners was 28 per cent in 20 Io (Nihon Bengoshi Rengokai, 20I Ib, p. I04). 


\section{Conclusion}

Academic interest in the sociology of law emerged in Japan among legal scholars who were struggling to make their interpretation of statutory provisions fit the social reality after the adoption of the Western European legal system. Because of this, the sociology of law has been treated as a science for legal scholars to understand social reality, and the subject developed as an empirical social science in Japan. Ehrlich's scheme of how living law grew into legal provisions inspired legal scholars to discover living law in their attempt to show how legal provisions would be interpreted to fit social reality. Though such concerns continued in the post-war period, Kawashima turned the scheme upside-down, emphasising that the new Constitution should become Japan's 'living law'. Here we can see how the interplay of society and law was viewed in different political conditions. The Justice System Reform provided another opportunity for legal sociologists to observe the effects and limitations of using law to change society. The centrality of empirical studies does not mean that there have been few theoretical studies. Though this paper has focused on empirical studies, there have been plenty of theoretical studies, as Japanese scholars have always been keen on new developments of the sociology of law in foreign countries. ${ }^{70}$ However, what has been considered to be the core part of the sociology of law is empirical research. ${ }^{\text {I }}$

The sociology of law was considered as a branch of legal scholarship even before World War II, partly because few scholars in sociology worked on law and legal institutions at that time. Kawashima succeeded in making the sociology of law a branch of legal scholarship. Since he taught the sociology of law, it has been taught to law students in undergraduate and graduate programmes of law at Japanese universities, and an increasing number of universities have included the subject in their law curricula. The sociology of law remains a major subject of law study even after the establishment of the new professional law schools. ${ }^{72}$

As we have shown, the Justice System Reform gave unprecedented opportunities for Japanese legal sociologists to conduct large-scale quantitative research. Until the last decades of the twentieth century a rather limited number of legal sociologists as well as legal psychologists sought to expand the research field of the sociology of law in Japan. Since the Justice System Reform began, however, a much larger number of social scientists with legal backgrounds have engaged in empirical work, further expanding the field of the sociology of law. Before the Justice System Reform, nationwide surveys were rare, but not any more. At the same time, academic research has been increasingly oriented towards policy questions. This is in a sense inevitable. As a large-scale survey needs a large budget, usually provided by public funds, it needs to be useful for the taxpayers. However, research for policy can also be designed to answer theoretical questions. In this sense, we now have plenty of data obtained by surveys on legal problems, civil litigation, the lay judge system and others. But the theoretical implications of the research findings have not been fully analysed or discussed. This will be a significant agenda for us to go forward to the next stage of development in the sociology of law.

There is another new development in the sociology of law in Japan. That is, in the last decade, sociologists without legal backgrounds have finally begun to join empirical research on law and

70 Many theoretical studies focused on introducing foreign theories in Japan, rather than developing original ideas or theories. Masaji Chiba, who started as a legal ethnographer, became a legal anthropologist and tried to develop an original general theory of law drawing upon his empirical studies on Asian indigenous law (Chiba 1986, I998).

7I Empirical research distinguishes the sociology of law from neighbouring fields of law such as jurisprudence, the philosophy of law and doctrinal legal studies.

72 When new professional law schools were planned, there were concerns among scholars in the sociology of law that new law schools would eliminate the subject from their curriculum. However, the sociology of law seems to be chosen, together with the philosophy of law, as a major subject outside ordinary law subjects. 
legal institutions. The sociology of law was monopolised by legal scholars for a long time. But barriers surrounding law seem to be becoming lower, and law is less foreign to scholars without legal backgrounds. Participation of pure social scientists in the sociology of law may change basic concerns shared among legal sociologists in Japan. But so far, comparison between legal provisions and practice, 73 on the one hand, and Japan and the West, on the other, has been the main concern among Japanese legal sociologists. The Justice System Reform encouraged research on the first of these and research of this kind will continue to be conducted. As for the Japan West comparison, the focus here seems to be changing from the normative to the empirical, as views of the West are becoming more realistic, in other words, more sociological. Yet, research based on this concern will also continue to be done. Being at the crossroads of these two concerns is the distinctive position of the sociology of law in Japan in the global context, as Kawashima's work indicated.

\section{References}

ABE, Masaki (2002) Rokaruna Ho Chitsujo - Ho to Kosaku suru Kyodosei [Local Legal Order - Communality Cutting Across the Law]. Tokyo: Keiso Shobo.

ABE, Masaki (2009) 'Citizens' Evaluations of Institutional Advice Providers Used for Dealing with Everyday Problems in Japan', Societas/Communitas I(7): 8I-100.

BAYLEY, David H. (I 976) Forces of Order: Police Behavior in Japan and the United States. Berkeley: University of California Press. Revised edition published as Forces of Order: Policing Modern Japan (I99I).

сніва, Masaji (ed.) (I986) Asian Indigenous Law: Interaction with Received Law. London/New York: RKI. снівA, Masaji (I998) Ajia Ho no Tagenteki Kozo [Plural Structure of Asian Law]. Tokyo: Seibundo.

DAISHIN'IN MINJI RENGOBU HANKETSU (I9I5) 26 January I9I5, Daihan Minroku 49.

EHRLICH, Eugen (I9I3) Grundlegung der Soziologie des Rechts. München: Duncker \& Humblot.

EHRLICH, Eugen (I920) 'Seibun Ho to Ikita Ho' ['Written Laws and Living Law', trans. Hideo Hatoyama],

Hogaku Kyokai Zasshi 38: I509-36; original German text Gesetz und lebendes Recht at the end of issue 38(I 2): I-XXII.

EHRLICH, Eugen (I922a) 'Horitsu Shakaigaku' ['The Sociology of Law', trans. Kenzo Takayanagi],

Hogaku Kyokai Zasshi 40: I-4I; original German text Die Soziologie des Rechts at the end of issue 4O(I): III-XXII.

EHRLICH, Eugen (I922b) 'The Sociology of Law', trans. Nathan Isaacs, Harvard Law Review 36: I 29-45. eHrLICH, Eugen (I 936) Fundamental Principles of the Sociology of Law, trans. Walter L. Moll. Cambridge,

MA: Harvard University Press.

foote, Daniel H. (I992) 'The Benevolent Paternalism of Japanese Criminal Justice', California Law Review 80: 317-90.

FOote, Daniel H., KaWai, Mikio, moriya, Akira, Kakiuchi, Shusuke, Kaminaga, Yuriko, WadA, Ysuhiro, maEdA, Tomohiko and отA, Shozo (2009) 'Attitudes, Evaluation, and Decision-Making by Civil Litigants and Their Lawyers: Findings from the Nationwide Survey (I) (2)', Meijo Hogaku 58(3): 9I-I58, 58(4): 86-I68.

Fооте, Daniel H. and ота, Shozo (eds) (2010) Saiban Keiken to Sosho Kodo [Litigation Experience and Litigation Behavior], Gendai Nihon no Hunso Shori to Minji Shiho [Dispute Resolution and Civil Justice in Contemporary Japan] 3. Tokyo: University of Tokyo Press.

73 Such studies can be 'gap' studies that contrast legal provisions and their effects. But, as we saw above, Japanese scholars more often tried to see how a legal provision was 'interpreted' in practice, rather than how effective a legal provision was, probably because most Japanese legal sociologists have legal backgrounds. As more sociologists without legal backgrounds come to study law and legal institutions, there may be more empirical studies of the effects of the law. 
FRANK, Jerome (1974) Ho to Gendai Seishin [Law and the Modern Mind, trans. Takao Tanase and Kazuyo Tanase]. Tokyo: Kobundo; originally Law and Modern Mind (I963), Garden City, NY: Anchor Books.

HALEy, John O. (I978) 'The Myth of the Reluctant Litigant', Journal of Japanese Studies 4: 359-90.

Haley, John O. (I99I) Authority without Power: Law and the Japanese Paradox. New York: Oxford University Press.

hamano, Ryo (I993-94) 'Bengoshi niyoru Kigyo Homu no Shori - Tokyo niokeru Jittai Chosa wo humaete' ['Legal Practice for Corporations - Based on Empirical Research in Tokyo'], NBL 530: 6-I 7, 532: 35-4I, 533: 35-39 (I993), 537: 36-4I, 539: 38-4I, 542: 43-47, 550: 60-7I, 552: 6I-65, 555: 42-49, 557: 47-5I, 558: 6I-66, 559: 52-57 (I994).

hamano, Ryo (2007) 'The Turn Toward Law: The Emergence of Corporate Law Firms in Contemporary Japan', in William P. Alfred (ed.), Raising the Bar: The Emerging Legal Profession in East Asia. Cambridge, MA: East Asian Legal Studies, Harvard Law School.

HAMilton, V. Lee and sAnders, Joseph (1992) Everyday Justice: Responsibility and the Individual in Japan and the United States. New Haven: Yale University Press.

HaSegawa, Kiyoshi (2006) Toshi Community to Ho - Kenchiku Kyotei / Chiku Keikaku niyoru Kokyo Kukan no Keisei [Urban Community and the Law - Formation of Public Space by Construction Agreement / District Zoning]. Tokyo: University of Tokyo Press.

haYaKawa, Takeo (I966) 'Amerika niokeru Shiho Katei to Kodo Kagaku' ['Judicial Process and Behavioral Science in America'], Horitsu Jiho 38(4): I4-22.

HeInZ, John P. and Laumann, Edward O. (I982) Chicago Lawyers: The Social Structure of the Bar. New York: Russell Sage Foundation; Chicago: American Bar Foundation; revised edition (I994), Evanston, IL: Northwestern University Press; Chicago: American Bar Foundation.

Heinz, John P., nelson, Robert L., SANDefur, Rebecca L. and Laumann, Edward O. (2005) Urban Lawyers: The New Social Structure of the Bar. Chicago: University of Chicago Press.

HERTOGH, Marc (20I2) 'Mind the (new) gap: A Selective Survey of Current Law and Society Research in the Netherlands', International Journal of Law in Context 8(I): I37-53.

hirano, Ryuichi (I958) Keiji Sosho Ho [Criminal Procedure]. Tokyo: Yuhikaku.

hirano, Ryuichi (I985) 'Genko Keiji Sosho no Shindan', in Yasuharu Hiraba (ed.), Dando Shigmitsu Hakase Koki Shukuga Ronbunshu [Festschrift for the 7oth Birthday of Dr. Shigemitsu Dando]. Tokyo: Yuhikaku, 4: 407-23.

IsHimuRA, Zensuke (I966) 'Bengoshi Katsudo no Senmon Bunka, Kyodoka, Taishuka - Bengoshi no Shokugyo Shakiagakuteki Ichi Kosatsu' ['Specialisation, Combination and Popularisation of Lawyers' Activities - A Consideration on Lawyers from a Point of the Sociology of Occupation'], Horitsu Jiho 38(4): 23-33.

IsHimura, Zensuke (1969) Gendai no Professhon [Modern Profession]. Tokyo: Shiseido.

ishimura, Zensuke, tokoro, Kazuhiko and nishimura, Haruo (I986) Sekinin to Batsu no Ishiki Kozo

[Cognitive Structure of Responsibility and Punishment]. Tokyo: Taga Shuppan

KAINo, Michitaka (I943a) Horitsu Shakaigaku no Shomondai [Issues of the Sociology of Law]. Tokyo: Nihon Hyoronsha.

KAINo, Michitaka (I943b) Iriai no Kenky [Study of Common]. Tokyo: Nihon Hyoronsha.

Kashimura, Shiro and bushimata, Atsushi (eds) (2010) Toraburu Keiken to Sodan Kodo [Trouble Experience and Advice Seeking Behavior], Gendai Nihon no Hunso Shori to Minji Shiho [Dispute Resolution and Civil Justice in Contemporary Japan] 2. Tokyo: University of Tokyo Press.

KATO, Masanobu, FUjImoto, Akira and Ho ISHIKI KOKUSAI HIKAKU KENKYUKAI, Masanobu [Research Group for International Comparison of Legal Consciousness] (2003) 'Keiyaku Ishiki no Kokusai Hikaku - 22 ka Koku/Chiiki Jittai Chosa kara' ['Multinational Comparison of Contract Consciousness from Research in 22 Countries/Areas'], Nagoya Daigaku Hosei Ronshu I96: I-4I9. 
като, Masanobu and ғUјммото, Akira (2006) Nihonjin no Kieyakukan - Keiyaku wo Mamoru Kokoro to Yaburu Kokoro [The Japanese View of Contract - Mind to Abide Contract and to Break Contract]. Tokyo: Sanseido.

kawashima, Takeyoshi (n.d.) 'Chapter 6: Consciousness on Crime and Punishment', filed at Kawashima Collection, Sapporo University Library.

KAWASHIma, Takeyoshi (I946a) 'Jumpo Seishin no Seishinteki oyobi Shakaiteki Kozo' ['The Mental and Social Structure of the Law Abiding Spirit'] (I)-(2), Hogaku Kyokai Zasshi 64: 393-4I6, 527-55. Kawashima, Takeyoshi (I946b) 'Nihon Shaki no Kazokuteki Kosei' ['Construction of the Japanese Society as Family'], Chuo Koron 6I(6): 27-37.

KaWASHIma, Takeyoshi (I949) Shoyuken Ho no Riron [Theory of Property Ownership]. Tokyo: Iwanami Shoten.

Kawashima, Takeyoshi (1950) “'Ko Do” no Shakaiteki Kozo to Kindaika no Unmei' ['The Social Structure of "Familial Piety Doctorine" and the Fate of Modernization'], Chuo Koron 65(9): 95-IoI. Kawashima, Takeyoshi (I95Ia) 'Ehrlich no Jitsuyo Hogaku Hihan' ['Ehrlich's Criticism of the Practical Juriprudence'], Hoshakaigaku [The Sociology of Law] I: I39-55.

KAWASHIma, Takeyoshi (I95Ib) “'On” no Ishiki no Jittai' ['The Reality of the Consciousness of "On”'], Chuo Koron 66(3): II9-29.

KAWASHIMA, Takeyoshi (I95IC) 'Giri', Shiso 327: 2 I-28.

KAWASHIma, Takeyoshi (I957) Ideology toshiteno Kazoku Seido [The Institution of Family as Ideology]. Tokyo: Iwanami Shoten.

KawaShima, Takeyoshi (I959) 'Jumpo Seishin' ['Law-Abiding Spirit'], in Kindai Shakai to Ho [Modern Society and the Law]. Tokyo: Iwanami Shoten, 55-II7.

KawaShima, Takeyoshi (I960) 'Shakai Kozo to Saiban - Meiji igo no Shakai Kozo to Saiban Seido tono Kankei' ['Social Structure and Adjudication - The Relationship between the Social Structure since the Meiji Era and the Institution of Adjudication'], Shiso 432: I-I7.

KaWAShima, Takeyoshi (1963) 'Dispute Resolution in Contemporary Japan', in Arthur T. von Mehren (ed.), Law in Japan - The Legal Order in a Changing Society. Cambridge, MA: Harvard University Press; Tokyo: Charles E. Tuttle Company, 4I-72.

Kawashima, Takeyoshi (I966) 'Nihonjin no Kenri Ishiki - "Kindaika Hyakunen" no hitotsu no Sokumen' ['The Rights Consciousness of the Japanese People - An Aspect of "Modernization for a Hundred Years"'], Sekai 248: 43-67.

kawashima, Takeyoshi (I967) Nihonjin no Ho Ishiki [Japanese Legal Consciousness]. Tokyo: Iwanami Shoten.

KAWASHima, Takeyoshi (I972a) '“Ho” no Shakaigaku Riron no Kisozuke' ['Foundation of Sociological Theory of "Law", in Ho Shakaigaku Koza [Lectures in the Sociology of Law]. Tokyo: Iwanami Shoten, 4: 323-54.

KAWASHima, Takeyoshi (I 972 b) 'Hunso Kaiketsu to Hoteki Seigyo - Hoteki Seigyo no Hunso Moderu'

['Dispute Resolution and Legal Control - Dispute Model of Legal Control'], in Ho Shakaigaku Koza [Lectures in the Sociology of Law]. Tokyo: Iwanami Shoten, 5: I I-37.

KAwASHIMA, Takeyoshi (I972C) Kawashima Takeyoshi Chosakushu[The Works of Takeyoshi Kawashima] 4. Tokyo: Iwanami Shoten.

KAWASHIma, Takeyoshi (I 974) 'The Legal Consciousness of Contract in Japan', trans. Charles R. Stevens Law in Japan 7: I-2I.

Kawashima, Takeyoshi (I978) Aru Hogakusha no Kiseki [A Life of a Legal Scholar]. Tokyo: Yuhikaku. KAWASHIMA, Takeyoshi and Ishimura, Zensuke (ig64) 'Amerika Shakaigaku no Myakudo' ['Dynamic Beats of the American Sociology of Law'], Horitsu Jiho 36(4): 39-53.

Kawashima, Takeyoshi and watanabe, Yozo (I944) 'Ko no Kanko to Noson Seikatsu - Naganokenka Inagun Kamikugatamura no Chosa' ['The Custom of Ko and the Life of a Rural Village - 
Research on Kamikugata Village, Ina County, in Nagano Prefecture'] (I)-(2), Hogaku Kyokai Zasshi 62: 54I-87, 932-55.

LuHmann, Niklas (I977) Ho Shakaigaku [Sociology of Law], trans. Jun'ichi Murakami and Kahei

Rokumoto. Tokyo: Iwanami Shoten: originally Rechtssoziologie (I972), Reinbek bei Hamburg:

Rowohlt.

MAEda, Tomohiko (2009) 'Horitsu Mondai to Senmonka Sodan: Internet Chosa no Kanosei' ['Legal

Problems and Professional Consultation: The Possibility of Internet Research'], in Shozo Ota,

Daniel Foote, Ryo Hamano and Masayuki Murayama (eds), Hoshakaigaku no Shin Sedai [New

Generation of the Sociology of Law]. Tokyo: Yuhikaku, 98-122.

MAKINo, Eiichi (I950) 'Kazoku Kyodotai no Kaiho to Togo' ['Liberation and Integration of the Familial

Collectivity'], Chuo Koron 65(9): 78-94.

matsumura, Yoshiyuki, fujimoto, Akira, Kinoshita, Manako, yamada, Hiroko, fujita, Masahiro and коваYASHI, Chihiro (2007a) 'Japanese Attitudes Toward the Law and the Legal System: Its

Theoretical Model and Research Design', Chiba Journal of Law and Politics 22(I): I76-2 I4.

matsumura, Yoshiyuki, fujimoto, Akira, Kinoshita, Manako, yamada, Hiroko, fujita, Masahiro and коBAYASHI, Chihiro (2007b) 'Japanese Attitudes Toward the Law and the Legal System: An Outline of the Research Conducted in 2005', Chiba Journal of Law and Politics 22(2): 5I-I30.

matsumura, Yoshiyuki, kinoshita, Manako, ғujimoto, Akira, yamada, Hiroko, fujita, Masahiro and ковAYASHI, Chihiro (2007c) 'What are the Changes in Attitudes of Japanese People Toward the Law and the Legal System? Surveyed in I971, I976, and 2005', Chiba Journal of Law and Politics 22(3): II 2-6I.

matsumura, Yoshiyuki, kinoshita, Manako, ota, Shozo and yamada, Hiroko (2008) 'Tapanese Attitudes toward the Lay Judge System and Criminal Justice', Chiba Journal of Law and Politics 23(3): 204-84. matsumura, Yoshiyuki, kinoshita, Manako, ota, Shozo and yamada, Hiroko (2012) 'Japanese Attitudes toward the Lay Judge System and Criminal Justice: Based on the Second Survey Conducted in 2010', Chiba Journal of Law and Politics 27(I): 178-282.

matsumura, Yoshiyuki and murayama, Masayuki (eds) (2010) Hosihiki to Hunso Kodo [Legal Consciousness and Disputing Behavior], Gendai Nihon no Hunso Shori to Minji Shiho [Dispute Resolution and Civil Justice in Contemporary Japan] I. Tokyo: University of Tokyo Press.

MinPo hanRei KenkyUKai (I 923) Hanrei Minpo: Taisho IoNendo [Civil Law Precedents: Year of I 923 ]. Tokyo: Yuhikaku.

мiтo, Shinzo (I9I2) ‘Doitsu ni okeru Jiyuho Gakuha no Gaikan’ ['An Overview of the Free Law School in Germany'], Hogaku Kyokai Zasshi 30: I943-80.

Mitsui, Makoto (I970-77) 'Kensatsukan no Kiso Yuyo Sairyo-Sono Rekishiteki oyobi Jisshoteki

Kenkyu' ['Prosecutors' Discretion on Prosecution-Its Historical and Empirical Study'], Hogaku Kyokai Zasshi 87: 897-944 (I970), 9I: I047-9I, I3I9-65, I693-738 (I974), 94: 852-905 (I977). miyazawa, Setsuo (I985) Hanzai Sosa wo meguru Daiissen Keiji no Ishiki to Kodo - Soshikinai Tosei eno

Ninshiki to Hanno [The Consciousness and Behaviour of Front-Line Detectives in Crime Investigation Perception and Responses]. Tokyo: Seibundo.

miyazawa, Setsuo (I987) 'Taking Kawashima Seriously: A Review of Japanese Research on Japanese Legal Consciousness and Disputing Behavior', Law and Society Review 2I(2): 219-42.

miyazawa, Setsuo (I992) Policing in Japan: A Study on Making Crime, trans. Frank G. Bennett, Jr.. New York: State University of New York Press.

miYAZAWA, Setsuo (2007) 'The Politics of Judicial Reform in Japan: The Role of Law at Last?', in William P. Alford (ed.), Raising the Bar: The Emerging Legal Profession in East Asia. Cambridge, MA: East Asian Legal Studies, Harvard Law School, ro7-62.

miyazawa, Setsuo, bushimata, Atsushi, fujimoto, Akira and ageishi, Keiichi (20r2) 'Nihon nioite Tokutei Bunya heno Sotaiteki Shuchudo ga Takai Bengoshi no Zokusei - 2008 Nen Zenkoku Bengoshi Chosa Dai San Po' ['Characteristics of Lawyers Who Were Relatively Highly 
Specialized in Specific Fields in Japan - The Third Report of National Lawyers Survey in 2008'], Aoyama Homu Kenkyu Ronshu 5: I I9-233.

miYazawa, Setsuo, bushimata, Atsushi, ishida, Kyoko and ageishi, Keiichi (20II) 'Nihon niokeru Bengoshi no Senmon Bunka - 2008 Nen Zenkoku Bengoshi Chosa Dai Ni Ho' ['Specialization of Lawyers in Japan - The Second Report of National Lawyers Survey in 2008'], Aoyama Homu Kenkyu Ronshu 4: 193-287.

miyazawa, Setsuo, fujimoto, Akira, bushimata, Atsushi, Kaminaga, Yuriko, ageishi, Keiichi, ishida, Kyoko and OsAKA, Eri (2010) 'Hoka Diagakuin Kyoiku ni Kitai sareru "Hoso no Mind to Skill" ni taisuru Bengoshi no Iken - 2008 Nen Zenkoku Bengoshi Chosa Dai Ippo' ['Lawyers' Opinions on "Mind and Skill of Legal Professional" Expected to be Trained at Law Schools The First Report of National Lawyers Survey in 2008'], Aoyama Homu Kenkyu Ronshu 2: 67-I7I. MoRIYA, Akira (20II) 'Sosho no Teiki to Wakai no Sentaku: Sairon - Saibankan no Wakai Kanshi / Bengoshi no Risuku Kaihi / Sosho Tojisha no Kigakari' ['Bringing a Lawsuit and Choosing Settlement: Revisited - Judge's Advice to Settle / Risk Avoidance of Lawyers / Concern of Litigants'], Ho to Seiji 62(I,II): 6I-98.

murayama, Masayuki (1990) Keira Keisatsu no Kenkyu [A Study of the Patrol Police]. Tokyo: Seibundo. murayama, Masayuki (I992) 'Postwar Trends in the Administration of Japanese Criminal Justice: Lenient but Intolerant or Something Else?', Journal of Japan-Netherlands Institute 4: 22 I-46. murayama, Masayuki (I996) 'Hanzai no Ninchi/Kenkyo to Keisatsu Sairyo' ['Formal Recognition/ Clearance of a Crime and Police Discretion'], in Setsuo Miyazawa and Yuriko Kaminaga (eds), Ho Shakaigaku Colloquium: Ishimura Zensuke Sensei Koki Kinen Ronbunshu [Colloquium of the Sociology of Law: Festschrift for Professor Zensuke Ishimura's 7oth Birthday]. Tokyo: Nihon Hyoronsha, 373-9I. murayama, Masayuki (2002) 'The Role of the Defense Lawyer in the Japanese Criminal Process', in Malcolm M. Feeley and Setsuo Miyazawa (eds), The Japanese Adversary System in Context: Controversies and Comparisons. New York: Palgrave Macmillan, 42-66.

murayama, Masayuki (in collaboration with Ryo Hamano, Isamu Sugino, Ichiro Ozaki, Keiichi Ageishi, Satoshi Minamikata and Teiko Tamaki) (2007) 'Experiences of Problems and Disputing Behaviour in Japan', Meiji Law Journal I4: I-59.

murayama, Masayuki (2009) 'Expanding Access to Lawyers: The Role of Legal Advice Centers', in Rebecca L. Sandefur (ed.), Access to Justice: Classical Approaches and New Directions. Bingley: Emerald Group Publishing Limited, I67-20I.

mURAYAMA, Masayuki, moRIYA, Akira, ISHIDA, Kyoko, MAEDA, Tomohiko, niKI, Tsuneo and ono, Rie (20Io) 'Wagakuni niokeru Horitsu Sodan Riyo no Jittai' ['Actual Situation of the Use of Legal Consultation in Japan'], Horitsu Ronso 83(I): 4I I-58.

NAKADA, Kaoru (I9I3) 'Huransu ni okeru Jiyuho Ron' ['The Free Law Theory in France'], Hogaku Kyokai Zasshi 31: 40-75.

NAKAGAWA, Zennosuke (I926) 'Kon'in no Gishiki' ['Ritual for Marriage'] (4), Hogaku Kyokai Zasshi 44: 889-908.

NAKaGawa, Zennosuke (I95I) 'Kesen no Gyogyo kazoku' ['Fishermen Families in Kesen'], Hoshakaigaku [The Sociology of Law] I: 65-94.

NIHON BENGOSHI RENGOKAI (I99I) 'Nihon no Horitsu Jimusho I990-Bengoshi Gyomu no Keizaiteki Kiban ni kansuru Jittai Chosa Hokokusho' ['Law Offices in Japan I990-Report of the Survey on the Economic basis of Lawyers' Practice'], Jiyu to Seigi 42(I3): I-208.

NIHON BENGOSHI RENGOKAI (2002) 'Nihon no Horitsu Jimusho 2000-Bengoshi Gyomu no Keizaiteki Kiban ni kansuru Jittai Chosa Hokokusho' ['Law Offices in Japan 2000-Report of the Survey on the Economic basis of Lawyers' Practice'], Jiyu to Seigi 53(I3): I-34I.

NIHON BENGOSHI RENGOKAI (20IIa) 'Nihon no Horitsu Jimusho 20 Io - Bengoshi Gyomu no Keizaiteki Kiban ni kansuru Jittai Chosa Hokokusho' ['Law Offices in Japan 2010 - Report of the Survey on the Economic basis of Lawyers' Practice'], Jiyu to Seigi 62(6): I-299. 
NIHON BENGOSHI RENGOKAI (20IIb) Bengoshi Hakusho 20I I Nen Ban [White Paper on the Lawyers 20 I I Edition]. Tokyo: Hihon Bengoshi Rengokai.

NIHON BENGOSHI RENGOKAI, BENGOSHI GYOMU TAISAKU IINKAI (I98I) 'Bengoshi Gyomu no Keizaiteki Kiban ni kansuru Jittai Chosa Kihon Hokoku' ['Basic Report of the Survey on the Economic Basis of Lawyers' Practice'], Jiyu to Seigi 32(I0): I-I49.

NiHON BUnKa KaIgr (ed.) (I973) Nihonjin no Ho Ishiki <Chosa Bunseki> [The Legal Consciousness of the Japanese <Research and Analyses >]. Tokyo: Shiseido.

NiHOn BUnKa KAIGI (ed.) (I982) Gendai Nihonjin no Ho Ishiki [The Legal Consciousness of the Contemporary Japanese]. Tokyo: Daiichi Hoki Shuppan.

NONET, Phillippe and Selznick, Philip (I98I) Ho to Shakai no Hendo Riron [Theory of Change in Law and Society, trans. Kahei Rokumoto]. Tokyo: Iwanami Shoten; originally Law and Society in Transition: Toward Responsive Law (1978), New York: Octagon Books.

окI, Masao (I983) Nihonjin no Ho Kannen - Seiyoteki Ho Kannen tono Hikaku [The Idea of Law among the Japanese - Comparison with the Western Idea of Law]. Tokyo: University of Tokyo Press.

ono, Seiichiro (I924) 'Pound no Horigaku nit suite' ['On Pound's Jurisprudence'] (I)-(3), Hogaku Kyokai Zasshi 42: 2I-45, 213-38, 4I5-4I.

ота, Shozo (2009) 'Minji Hunso niokeru Kosho Performance to Personality Tokusei' ['Negotiation Performance and Personality Characteristics in Civil Disputes'], in Shozo Ota, Daniel Foote, Ryo Hamano and Masayuki Murayama (eds.), Hoshakaigaku no Shin Sedai [New Generation of the Sociology of Law]. Tokyo: Yuhikaku, 305-45.

OZAKI, Ichiro (I996) 'Toshi no Kokyosei to Ho - Manshon ni okeru Seikatsu to Kanri' ['Public Sphere and Law in an Urban Area - Life and Management in Condominiums'] (I)-(4), Hogaku Kyokai Zasshi II3: I324-84, I465-5I8, I533-90, I685-723.

PODGORECKI, Adam, KAUPEN, Wolfgang, vAn houtte, J., vinke, P. and Kutchinsky, Berl (I973) Knowledge and Opinion about Law. London: Martin Robertson.

RAMSEYER, J. Mark (I990) Ho to Keizaigaku - Nihon Ho no Keizai Bunseki [Law and Economics-Economic Analysis of Japanese Law]. Tokyo: Kobundo.

roкuмото, Kahei (I97I) Minji Hunso no Hoteki Kaiketsu [Legal Resolution of Civil Disputes]. Tokyo: Iwanami Shoten.

RокUмото, Kahei (I972 \& I973) 'Problems and Methodology of Study of Civil Disputes Part I \& Part II', Law in Japan 5: 97-I I4, 6: I I I-27.

Rокимото, Kahei (I986) Ho Shakaigaku [Sociology of Law]. Tokyo: Yuhikaku.

roкuмото, Kahei (I988) 'The Present State of Japanese Practicing Attorneys: On the Way to Full

Professionalization?', in Richard L. Abel and Philip S.C. Lewis (eds), Lawyers in Society: The Civil Law World. Berkeley: University of California Press, r60-99.

Rокuмото, Kahei (2004) Nihon no Ho to Shakai [Japanese Law and Society]. Tokyo: Yuhikaku. RокUмото, Kahei and yosнida, Yuichi (eds) (2007) Suehiro Izutaro to Nihon no Ho Shakaigaku [Suehiro Izutaro and the Sociology of Law in Japan]. Tokyo: University of Tokyo Press.

SAIKo SAibansho [The Supreme Court] (2009, 2010, 20I I, 2012) Saiban'in'to Keikensha ni taisuru Anketo

Chosa Kekka Hokokusho [Report on Results of Questionnaire Research of Those Who Served as Saiban'in and Others]. Online: [2009]<http://www.saibanin.courts.go.jp/topics/pdf/09_I2_05-Iojissi_jyouk you/h2I_siryor.pdf〉; [20Io] 〈http://www.saibanin.courts.go.jp/topics/pdf/o9_I2_05-Iojissi_jyou kyou/h22_keikensya.pdf〉; [20II] 〈http://www.moj.go.jp/content/oooog8676.pdf〉; [20I2] 〈http:// www.saibanin.courts.go.jp/topics/pdf/09_I2_05-Iojissi_jyoukyou/h24_keikensya.pdf〉 (last accessed 3 November 20I3).

SAPPORO DAIGAKU TOSHOKAN [Sapporo University Library] (I995) Kawashima Bunko Mokuroku

[Kawashima Collection Catalogue]. Sapporo: Sapporo Daigaku. SASAKI, Yoshio (1967) Minji Chotei no Kenkyu [Study of Civil Conciliation]. Kyoto: Horitsu Bunkasha. sueHiro, Izutaro (I924) Noson Horitsu Mondai [Legal Problems of the Agrarian Village]. Tokyo: Kaizosha. 
SueHiro, Izutaro (I926) Rodoho Kenkyu [Study of the Labor Law]. Tokyo: Kaizosha.

SueHiro, Izutaro (I940) ‘Chosa Hoshin ni kansuru Oboegaki' ['Memorandum for Research Guidelines'], reprinted in Chugoku Noson Kanko Chosa Kankokai (ed.), Chugoku Noson Kanko Chosa [Research on Customs in Chinese Agrarian Communities] I (I952). Tokyo: Iwanami Shoten, 2 I-26. SUEHIRO, Izutaro (I95I) 'Bokansha no Kotoba - Sokan no Ji' ['Words of a Spectator - Introduction for the First Issue'], Hoshakaigaku I: I-3.

Suehiro, Izutaro, ISODA, Susumu, UKaI, Nobushige, KaIno, Michitaka, KaWashima, Takeyoshi, HIRANo, Yoshitaro, hozumi, Shigeto, makino, Eiichi, miYazawa, Toshiyoshi, wagatsuma, Sakae, Ishimoto, Masao and Tsuj, Kiyoaki (I948) 'Zadankai: Nihon Hogaku no Kaiko to Tenbo' ['Roundtable: The Past and Future of Japanese Legal Scholarship’], Horitsu Jiho 20: 547-682.

sugawara, Ikuo, yamamoto, Kazuhiko and sato, Iwao (eds) (2010) Riyosha ga motomeru Minji Sosho no Jissen - Minji Sosho ha donoyoni Hyoka sareteiruka [Civil Litigation Practice Desired by Litigants: How Civil Litigation is Evaluated]. Tokyo: Nihon Hyoronsha.

taKayanagi, Kenzo and taKaHashi, Isamu (trans) (I9I5) 'Beikoku ni okeru Horitsu Tetsugaku - Pound Shi Shosetsu' ['Philosophy of Laws in the US - The Doctrine of Mr Pound'] (I), (2), (3), Hogaku Kyokai Zasshi 33: 339-550 [i.e. 539-50], 698-716 and 898-906; this is a translation of Pound's article in Kohler, Archiv für Rechts-und-Wirtsschaftsphilosophie, January, April I9I4.

tamaki, Teiko, maeda, Tomohiko, sugino, Isamu, minamikata, Satoshi and murayama, Masayuki (2009) 'Hunso Kodo Internet Chosa no Kihon Shukei' ['Basic Findings of an Internet Survey on Disputing Behavior'] (I), (2), Hosei Riron 4I(3/4): 205-40, 42(I): I57-80.

tanaka, Hideo (I980) 'Nihon niokeru Amerika Ho Kenkyu / Amerika niokeru Nihon Ho Kenkyu' ['Studies of American Law in Japan / Studies of Japanese Law in America'], Hikakuho Kenkyu 42: 46-7I.

TANASE, Takao (I983) Hon-nin Sosho no Shinri Kozo - Shiteki Jichi no Saiban Moderu [Trial Structure of Per Se Litigation - Adjudication Model of Self-Governance]. Tokyo: Kobundo.

tanaSe, Takao (1987) Gendai Shakai to Bengoshi [Modern Society and Private Attorneys]. Tokyo: Nihon Hyoronsha.

TANASE, Takao (I990) 'The Management of Disputes: Automobile Accident Compensation in Japan', Law and Society Review 24: 65I-92.

TANASE, Takao (I992) Hunso to Saiban no Ho Shakaigaku [The Sociology of Law of Disputes and Adjudication]. Kyoto: Horitsu Bunkasha.

TANASE, Takao (ed.) (I 994) Gendai no Huhokoi Ho: Ho no Rinen to Seikatsu Sekai [Contemporary Tort Law: The Legal Ideal and the World of Everyday Life]. Tokyo: Yuhikaku.

TANASE, Takao (ed.) (r 999) Keiyaku Hori to Keiyaku Kanko [Contract Principle and Contract Custom]. Tokyo: Kobundo.

TANASE, Takao (2003) Sosho Doin to Shiho Sanka - Shimin no Ho Shutaisei to Shiho no Seitosei [Mobilization for Litigation and Participation in Adjudication - The Citizen as Independent Subject and the Legitimacy of Adjudication]. Tokyo: Iwanimi Shoten.

TANASE, Takao (20I0) Community and the Law: A Critical Reassessment of American Liberalism and Japanese Modernity, trans. and ed. Luke Nottage and Leon Wolff. Cheltenham/Northampton, MA: Edward Elgar.

uesugi, Shinkichi (I913) 'Jiyuho Setsu Hi nari' '[The Free Law Doctrine is Wrong'], Hogaku Kyokai Zasshi 31: 75-85.

uPHAM, Frank K. (1987) Law and Social Change in Postwar Japan. Cambridge, MA: Harvard University Press.

ushiomi, Toshitaka (I95I) 'Note on the Annual Meeting', Hoshakaigaku [The Sociology of Law] I: I9I-94. VANOVERBEKE, Dimitri (2004) Community and State in the Japanese Farm Village: Farm Tenancy Conciliation (I924-I938). Leuven: Leuven University Press. 
WADA, Yoshitaka (I982) ‘Gendai Toshi Shakai niokeru Hunso Shori to Ho - Saibangai Hunso Shori to Senryakuteki Ho Shiyo' ['Dispute Resolution and the Law in Contemporary Urban Society - Outof-Court Dispute Resolution and Strategic Uses of the Law'] (I)-(3), Hogaku Ronso I I (2): 67-96, I I I (6): 58-88, I I 2(3): 72-97.

WAgATSuma, Sakae (I926a) 'America ni okeru Shakaigakuteki Horitsugaku' ['Sociological Jurisprudence in America'] (I), (2), Hogaku Shirin 28: 83I-54, 954-69.

Wagatsuma, Sakae (I926b) 'Shiho no Hohoron ni kansuru ichi Kosatsu' ['Reflection on the Methodology of the Private Law'] (I), (2), Hogaku Kyokai Zasshi 44: I003-38, I223-55.

WAllschlaeger, Christian (I997) 'Historical Trends of Civil Litigation in Japan, Arizona, Sweden, and Germany: Japanese Legal Culture in the Light of Judicial Statistics', in Harald Baum (ed.), Japan, Economic Success and Legal System. Berlin/New York: Walter de Gruyter, 89-I42. 